Research Shows

\title{
Community Education Has Promise
}

\author{
Curtis Van Voorhees \\ Peter J. Cwik \\ Marilyn J. King
}

Despite discouragement about what a couple of studies reveal about some administrators' views of community education, these authors are optimistic that the concept can help schools cope with today's problems and that, perhaps, it holds the key to positive change.

ommunity education, as a practice, is far from community education as a concept. That's the conclusion of some studies.

The staff at the Office of Community Education Research, The University of Michigan, has spent several months attempting to identify the current state of community education so far as practice, cost, attitudes, attendance, and results relative to hoped for and purported outcomes. While the results are not as promising as we had hoped, especially those of us in search of a panacea for education's problems, there are indications that community education has promise; especially if we are able to learn from our research.

\section{Too Few Are Involved}

Programmatically, community education is scarcely reaching beyond that of planned physical activity, formal adult education, and hobby classes. Certainly, there are a few schools or systems that program beyond these areas but they are the exception. In areas where those services did not exist prior to the introduction of community education, their presence can be viewed as a beginning. But in many communities, it seems likely that the only real change has been in the title; the same things are still offered by the same organizations in the same way.

Curtis Van Voorhees, Peter J. Cwik, and Marilyn J. King are on the School of Education staff at the University of Michigan, Ann Arbor. 
Too few schools-too few systems-have become involved in Community Education. School leaders do not give high priority to those activities outside the formal K-12 system which have a strong bearing on the school child.

Wagamon' found no difference in the priorities of community school and non-community school superintendents. Nearly 200 superintendents were asked to indicate the importance of 29 areas (e. g., language arts, guidance services) across five age groups (pre-school, elementary, junior high or middle school, high school, and adult). Preschool and adult groups were given lowest priority by the respondents. Language arts at the elementary, junior high, and high school was given the highest rating.

Seventeen of the first twenty-five ranked areas were high school activities, indicating that far less importance was attached to the school's role in the education of pre-schoolers, adults, and families. Guidance for elementary children ranked 82nd out of 145 with competitive sports, junior high publications, and similar areas ranking well above it.

Seemingly, community educators must revise the priorities of educational leaders before community education can begin to live up to its potential. Knowledge of sociology, human growth and development, and learning theory are but a few of the areas in which leaders need information if they are to intelligently prioritize the potential activities of the schools.

\section{Decreases in Vandalism Noted}

School vandalism, a problem under serious study by the federal government, is an area in which community educators have long believed they could effect change. Palmer ${ }^{2}$ found significant decreases in school vandalism that corresponded with the introduction of community education in a small midwestern community. During the same period, auto theft, typically a teenage crime, also decreased.

The community studied had experienced a significant number of programs of recreational nature for several years prior to the introduction of community education. The real programmatic difference was the addition of adult and family educational experiences

\footnotetext{
'Thomas W. Wagamon, "Identifying the Priorities of Superintendents Regarding School Programs and Services to Traditional Schools and Community Schools." Unpublished doctoral dissertation. The University of Michigan, Ann Arbor, Mich. 1975.

${ }^{2}$ John L. G. Palmer, "A Study of the Community Education Program as a Deterrent to Violence and Vandalism in the Alma Community." Unpublished doctoral dissertation. The University of Michigan, Ann Arbor, Mich. 1975.
} 
to the activities carried on within the school. Palmer's facts were taken from local police records. The drop in vandalism to about one-third the level prior to community education is an indicator that the concept of opening schools to people outside the formal K-12 age may help reduce vandalism in the schools-may even pay for itself through reduced vandalism.

The American high school exists as a social system within the larger community. It has its own laws, mores, reward and punishment system, ruling class, codes of behavior, etc. Some have likened the high school to a prison; and, if they are right, perhaps community education holds a key to positive change.

The high school consists primarily of the rulers (teachers and administrators) and the ruled (students). No other group with a stake in the outcomes participates to any degree in the social structure of the high school. But parents and non-teaching adults could and should, according to community educators, participate in the structure. Parents, a group to whom the rulers and the ruled owe some allegiance, by attending classes and other activities in the high school during and after the school day, alter the social structure of the high school.

To both the ruler and the ruled, the parent represents authority. The parent becomes a spokesman for both groups-the link through which the student and teacher communicate with each other. The parent is, after all, both a teacher and a student. They can assume a supportive position to either group. They can influence both groups and, perhaps more importantly, both groups must listen. The student who knows that a parent is in the high school regularly is likely to act with greater responsibility just as the teacher is more likely to present a better lesson when a parent is present.

\section{Involving Parents}

PTAs have all but disappeared in high schools today but community education offers a means for parent involvement in another way. The parent becomes a participant, both in learning and in teaching. There is a difference between "telling" parent involvement such as that resulting from special interest parent groups, bent on making their special concern the number one activity of the school, and those who are themselves learners and/or teachers in the system.

Of course educators are often skeptical of parent involvement in the school but possibly an important natural resource-the learning parent-has been over-looked. Community educators believe parent involvement to be important and, thus far, our studies indicate they may be a real help in improving the climate of the high school itself through reduced vandalism. 
Research over the past two or three decades indicates the importance of the environment, the socio-economic situation, and the child's situation in the first five years of life to learning. The negativism in today's high schools doesn't just happen. It is the result of negligence at an earlier level and ignorance or inaction now. The high school should not operate in isolation from its community or the adult community models.

High school leaders should push for school intervention in the preschool years and at the same time encourage community intervention in the high school. Giving up some authority to gain better results is good business.

\section{Conclusion}

Conclusions drawn from studies of attendance in community school districts indicate the importance of selecting a coordinator of community school programs who relates well with local citizens. While the coordinator need not be exactly "like" the community, he must not possess the missionary notion of "change for the better and become what I am." Acceptance of the OK'ness of people's differences is an important pre-requisite to success as a community education leader.

So back to the beginning! Community education has yet to achieve many of its cherished claims. But there are indications that the inclusion of now teaching adults, especially parents, the mainstream and tributaries of the school system, will have positive benefits for students, teachers, and for the new participants themselves.

It is, however, up to the educational leaders to make the move that not only allows but encourages adult citizens' involvement in the schools. Given the priorities that Wagamon found, it seems likely that institutions of higher education must place greater emphasis on social psychology and learning theory in the training of principals in particular before this will come about.

If research indicates that we can reduce vandalism, thus, perhaps increasing pride in self and acceptance of the high school as something other than a prison, we believe the idea is worth exploring.

Our research has just begun. We hope to have more answers to the high school dilemma soon. Monographs on community education are available through the National Community Education Association, 1017 Avon Street, Flint, Mich. 48503. For additional information, write: Office of Community Education Research, Room 3112, School of Education, The University of Michigan, Ann Arbor, Mich. 48104. 